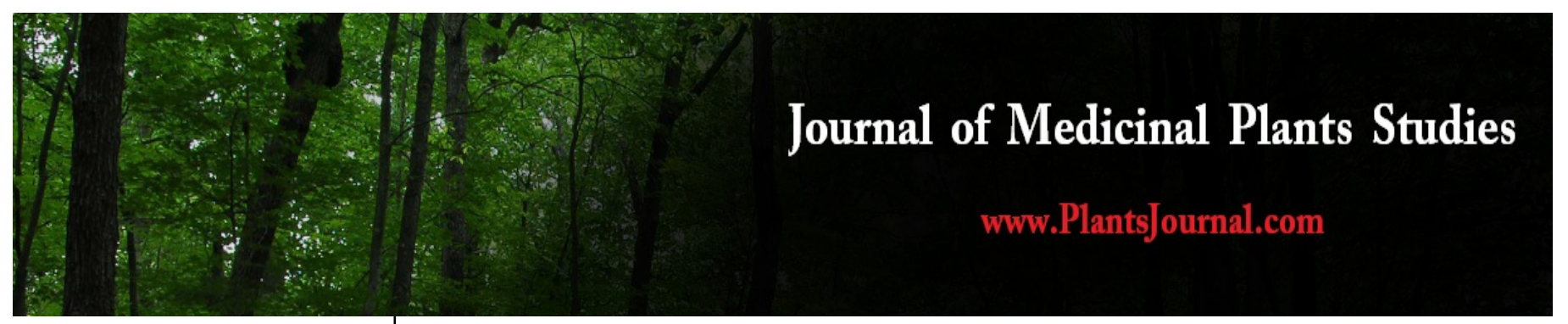

ISSN (E): 2320-3862

ISSN (P): 2394-0530

www.plantsjournal.com

JMPS 2021; 9(6): 10-15

(C) 2021 JMPS

Received: 07-09-2021

Accepted: 09-10-2021

Basunia RA

Department of Entomology,

Faculty of Agriculture Hajee

Mohammad Danesh Science and

Technology University (HSTU),

Dinajpur, Bangladesh

\section{Chowdhury SZ}

Assistant Manager, Seed

Marketing Department, Partex

Agro Limited, Bangladesh

\section{Bari SMW}

Deputy Director, BADC, Dhaka, Bangladesh

Bachchu MAA

Professor, Department of

Entomology, Faculty of

Agriculture,

\section{Alim MA}

Professor, Department of

Entomology, Faculty of

Agriculture, Hajee Mohammad

Danesh Science and Technology

University (HSTU), Dinajpur,

Bangladesh

\section{Bhuyain MMH}

Professor, Department of

Entomology, Faculty of

Agriculture, Hajee Mohammad

Danesh Science and Technology

University (HSTU), Dinajpur,

Bangladesh

\section{Uddin MN}

Professor, Department of

Entomology, Faculty of

Agriculture, Hajee Mohammad

Danesh Science and Technology

University (HSTU), Dinajpur,

Bangladesh

\section{Corresponding Author:}

Uddin MN

Professor, Department of

Entomology, Faculty of

Agriculture, Hajee Mohammad

Danesh Science and Technology

University (HSTU), Dinajpur,

Bangladesh

\section{Acaricidal and repellent effects of Aloe vera $\mathrm{L}$. leaf extracts against Tetranychus urticae Koch (Acari: (Tetranychidae)}

\author{
Basunia RA, Chowdhury SZ, Bari SMW, Bachchu MAA, Alim MA, \\ Bhuyain MMH and Uddin MN
}

DOI: https://doi.org/10.22271/plants.2021.v9.i6a.1345

\section{Abstract}

The two-spotted spider mite, Tetranychus urticae Koch (Acari: Tetranychidae) is a cosmopolitan pest that causes considerable damage to vegetables, fruit and flower plants. The acaricidal, ovicidal and repellent activity of four different extracts of Aloe vera L. (Asphodelaceae) leaves were evaluated against $T$. urticae under laboratory conditions. Four different solvents of $A$. vera leaf extracts were tested against T. urticae at concentrations of $0.25,0.50,1.0$ and $2.0 \%$. The results indicated that all extracts had lethal and repellent effects on $T$. urticae. The acetone extract showed the highest mortality $(95.0 \%)$ of adult females followed by ethanol (83.0\%) at $2.0 \%$ concentration. The LC50 values of acetone, ethanol, methanol and petroleum ether extract for adult females were $0.446,0.667,0.953$ and 1.279 , respectively and for eggs were 0.950, 1.406, 2.115 and 3.312, respectively. The ethanol extract was found to be more effective as a repellent against adult females of $T$. urticae followed by acetone, methanol and petroleum ether causing a reduction in egg production per female by $96.0,94.0,85.0$ and $83.0 \%$, respectively. In the residual test, the acetone extract showed the highest mortality (49\%) after 1 hour of treatment followed by ethanol (43.0\%), methanol (29.0\%) and petroleum ether (25.0\%). The percent of mortality decreased after 48 and 72 hours after treatments. The results show that $A$. vera has a high potential to become a botanical acaricide for controlling T. urticae.

Keywords: A. vera, T. urticae, acaricidal activity, ovicidal activity, repellency

\section{Introduction}

The two-spotted spider mite (TSSM), Tetranychus urticae Koch (Acari: Tetranychidae) is known as a phytophagous pest of many cultivated crops throughout the world. This herbivore attacked a variety of cultivated crops and feeds over 1100 plant species in 140 families of economic importance value ${ }^{[1]}$. Both immature and adults of $T$. urticae suck sap from the lower surface of leaves ${ }^{[2]}$. Leaf curling, yellowing, bronzing, defoliation and even plant death occur due to the direct effect of mites feeding. Indirect effects of feeding result in reduced photosynthesis, transpiration, loss of green arena and ultimately, significant yield loss ${ }^{[3,4]}$. In the last few decades, control of the population of $T$. urticae has relied heavily on the continued use of acaricides or pesticides. A major problem with this pest is its ability to quickly develop resistance to certain acaricides or pesticides ${ }^{[5]}$. Besides resistance, the widespread use of traditional pesticides against mites can have serious effects on beneficial organisms, human health and the environment ${ }^{[6]}$. In order to achieve sustainable management of TSSM, it is important to reduce the use of synthetic acaricide or pesticides having a different mode of action ${ }^{[7,8]}$. Many plant extracts have a wide biological activity against insects and mites together with toxicity, repellence, oviposition deterrence, feeding and growth inhibition activity [9]. Unlike pesticides, numerous plant extracts have higher efficacy on pests, fast biodegradability, cheaper and have less impact on the environment ${ }^{[10,11]}$. Extensive research has been focused on the insecticidal activity of plant metabolites, which affect survival, growth, germination, nutrition, and various anatomical and biological processes of insects ${ }^{[12,13]}$. Aloe vera L., is a perennial herbaceous plant in the family Asphodelaceae. Known as medicinal aloe, its medicinal properties are widely recognized by traditional herbal medicine doctors and practitioners. Aloe vera plant contains over 160 chemical components and is used in 80 or more medicinal ingredients ${ }^{[14,15]}$. 
Aloin, one of the compounds, has antimicrobial, antifungal antibiotics, anti-oxidant activities and also plays an important role in the destruction of pests in granaries ${ }^{[16]}$ however, only toxicity and ovicidal activity have been recognized ${ }^{[17]}$. With respect to the benefits of aloe for humans, little is known about insecticidal and/or acaricidal activities. Therefore, the purpose of this study was to assess the acaricidal and repellent activity of $A$. vera leaf extracts against $T$. urticae.

\section{Materials and Methods}

The study was conducted from October 2017 to June 2018 in the laboratory of the Department of Entomology, Faculty of Agriculture, Hajee Mohammad Danesh Science and Technology University (HSTU) in Dinajpur, Bangladesh.

\section{Mite collection and rearing}

The adult mites, Tetranychus urticae were collected from an infested bean field of Hajee Mohammad Danesh Science \& Technology University campus, in 2017. Fifty percent of the collected mites were introduced on the country bean leaves grown in several plastic pots $(20 \mathrm{D} \times 20 \mathrm{H} \mathrm{cm})$ and placed in the front of the laboratory. Another fifty percent of the mites were reared on bean leaves in Petri dishes $(9 \mathrm{D} \times 2 \mathrm{H} \mathrm{cm})$. Fresh bean leaves were provided to replace the old dried leaves in the Petri dishes.

\section{Collection of plant materials}

Mature fresh Aloe vera L. leaves were collected from Anando nursery, Paharpur, Dinajpur, Bangladesh.

\section{Chemical Reagent}

Analytical grades of methanol, ethanol, acetone, petroleum ether were collected from (Daejung chemicals and metals Co. Ltd., Korea), (Merck KGaA, Germany), (Sigma-Aldrich Co.).

\section{Preparation of plant extracts}

Aloe vera leaves were collected and dried in the shade. After that, the leaves were cut into small pieces and finally dried again in an oven at a temperature of $50{ }^{\circ} \mathrm{C}$. The dried plant materials were ground to make fine powders of 80 meshes for extraction with four different solvents (acetone, ethanol, methanol and petroleum ether). 100 grams of $A$. vera powder was taken in a $600 \mathrm{ml}$ beaker and $300 \mathrm{ml}$ of acetone, ethanol, methanol and petroleum ether were added respectively. The mixtures were stirred by a magnetic stirrer (600 rpm) for 30 minutes and shaken by hand and allowed to stand for 72 hours. After that, the mixtures were filtered through filter paper (Whatman No. 1). The filtered materials were taken into a volumetric flask and the solvents were allowed to evaporate with the aid of a rotary evaporator $\left(50-60{ }^{\circ} \mathrm{C}\right)$. Finally, the crude extracts were stored in tightly corked glass vials and stored in the refrigerator at $3{ }^{\circ} \mathrm{C}$ for experimental use.

\section{Acaricidal effect on adults}

A group of $20 \mathrm{~T}$. urticae (24 h old) females was randomly selected from the stock culture and transferred to fresh bean leaf discs ( $3 \mathrm{~cm}$ in diameter) placed adaxial side up on moistened cotton in Petri dishes $(9 \mathrm{D} \times 2 \mathrm{H})$. Leaf discs were sprayed with four different solvent extracts of $A$. vera at four different concentrations $(0.25,0.50,1.0$, and $2.0 \%)$. A control test was considered performed using distilled water. Each treatment was repeated 4 times. A stereomicroscope (BST 606, Made in Germany) was used in this study to observe the alive and dead mites. The mites were considered dead if their appendages did not move when probed with a fine brush $24 \mathrm{~h}$ post-treatment. The mortality rate was calculated by using Abbott's corrected formula ${ }^{[18]}$.

\section{Ovicidal effect}

A bean leaf disc of approximately $3 \mathrm{~cm}$ in diameter was used as a substrate to oviposit. In each treatment, four leaf discs were used and fifteen female mites were placed upside down on hydrophilic cotton soaked in water in a Petri dish $(9 \mathrm{D} \times 2$ $\mathrm{H})$ and allowed to 5 hours to lay eggs. After 5 hours the adults were removed and the eggs were checked to ensure that at least 25 eggs, less than $24 \mathrm{~h}$ old will be laid on each disc. The leaf with egg were treated with four different concentrations $(0.25,0.50,1.0$ and $2.0 \%)$ of four different solvent extracts of A. vera with the help of a hand sprayer. A water spray control was also maintained. The eggs were observed for seven days till hatched. The numbers of hatched and non hatched eggs were recorded using a stereomicroscope.

\section{Repellency effect}

Leaf disc of bean along with midrib of $3 \mathrm{~cm}$ in diameter was used to evaluate the repellency of the four different solvent extracts of $A$. vera mixture. One part of the disc was dipped in the test concentrations of 10 seconds and the other half was used as a control. The treated discs were allowed to air dry for 30 minutes and then placed on moistened cotton in Petri dishes. Twenty adult females were put on the midrib of each disc. The experiment was replicated four times. The number of adult mites present on each half of the disc was recorded 24 hours after mite transfer. The number of eggs laid on both sides was also recorded under a stereomicroscope. The data were expressed as percentage repellency (PR) which was computed using the following formula described by McDonald et al. ${ }^{[19]}$ with some modifications.

$\operatorname{PR}(\%)=\left(\mathrm{N}_{\mathrm{C}}-50\right) \times 2$

Where, $\mathrm{N}_{\mathrm{C}}$ is the percentage of mites present in the untreated portion of the disc. Positive $(+)$ values expressed repellency and negative (-) values attractancy. The mean values were then categorized according to different class using the following range. Percent repellency $>0.01$ to $<0.1=$ class 0 ; 0.1 to 20 = class I; 20.1 to $40=$ class II; 40.1 to 60 = class III; 60.1 to $80=$ class IV; 80.1 to $100=$ class $\mathrm{V}^{[20]}$.

\section{Residual or persistence test}

The $\mathrm{LC}_{50}$ dose of four different solvent extracts of $A$. vera leaves was applied on the bean leaf disc $(3 \mathrm{~cm}$ diameter) with a hand sprayer. After 1, 24, 48 and $72 \mathrm{~h}$ of treatment 20 adult females of $T$. urticae were carefully released on the treated leaf discs. Each treatment was repeated 4 times. These mites were considered dead when they were unable to move even after probing with a brush.

\section{Statistical analyses}

Differences in mortality among treatments were analyzed for one way ANOVA using SPSS program Version 20.0 and means were compared using Tukey's test at $P<0.05$. Probit analysis was used to determine $\mathrm{LD}_{50}$ and $\mathrm{LD}_{90}$ using Polo Plus software ${ }^{[21]}$.

\section{Results and Discussion \\ Adult mortality of $T$. urticae of four different solvent extracts}

Acaricidal activity of four different solvent extracts of $A$. vera leaves was tested against $T$. urticae at four different concentrations $(0.25,0.50,1.0$ and $2.0 \%)$. Data presented in 
Table 1 indicates that, acetone extract of $A$. vera showed strong acaricidal activity against $T$. urticae followed by ethanol, methanol and petroleum ether extracts. At $0.25 \%$ concentration, acetone and ethanol extracts showed significantly higher acaricidal activity over control but there were no significant differences observed among the extracts. At $0.50 \%$ concentration acetone solvent extract exhibits higher mortality of mites which is significantly different from other extracts and control except for ethanol extract. At 1.0\% concentration mortalities in the four solvent extract treatments increased considerably compared to those at 0.25 and $0.5 \%$ concentration and acetone solvent extract were showed the highest mortality. At $2.0 \%$ concentration acetone extract achieved $94.81 \%$ mortality, followed by ethanol (81.82\%), methanol (71.43\%) and petroleum ether (61.04\%) (Table 1). The acetone solvent extract of $A$. vera was found to have good contact acaricidal activity against the $T$. urticae of female adult mites. Wei et al. ${ }^{[22]}$ stated that $24 \mathrm{~h}$ after treatment, the acetone extract of $A$. vera leaves showed the strongest acaricidal activity against $T$. cinnabarinus female adults. These findings were also supported by Zhang et al. ${ }^{[23]}$, who reported that the acetone extract of $A$. vera has a strong acaricidal activity against $T$. cinnabarinus female. Zhang et al. ${ }^{[24]}$ opined that acetone extract of $A$. vera leaves has acaricidal activity against $T$. cinnabarinus and $P$. citri. Amer et al. ${ }^{[25]}$ revealed that ethyl alcohol and acetone extracts were the most potent extracts against adult females of $T$. urticae.

Table 1: Adult mortality of $A$. vera leaf extracts at different concentrations recorded $24 \mathrm{~h}$ after exposure (Mean $\pm \mathrm{SE})(\%)$

\begin{tabular}{|c|c|c|c|c|}
\hline \multirow{2}{*}{ Extracts } & \multicolumn{4}{|c|}{ \% Concentrations } \\
\hline & 0.25 & 0.50 & 1.0 & 2.0 \\
\hline Acetone & $\begin{array}{c}30.00 \pm 4.56 \mathrm{a} \\
(27.27)\end{array}$ & $\begin{array}{c}48.75 \pm 5.54 a \\
(46.75)\end{array}$ & $\begin{array}{c}82.50 \pm 3.22 \mathrm{a} \\
(81.82)\end{array}$ & $\begin{array}{c}95.00 \pm 3.53 a \\
(94.81)\end{array}$ \\
\hline Ethanol & $\begin{array}{c}22.50 \pm 3.22 a \\
(19.48)\end{array}$ & $\begin{array}{c}35.00 \pm 4.56 \mathrm{ab} \\
(32.47)\end{array}$ & $66.25 \pm 4.26 b(64.94)$ & $\begin{array}{c}82.50 \pm .22 \mathrm{ab} \\
(81.82)\end{array}$ \\
\hline Methanol & $\begin{array}{c}18.75 \pm .26 \mathrm{ab} \\
(15.58)\end{array}$ & $\begin{array}{c}28.75 \pm 4.26 \mathrm{~b} \\
(25.97)\end{array}$ & $\begin{array}{c}50.00 \pm 4.56 \mathrm{c} \\
(48.05)\end{array}$ & $\begin{array}{c}72.50 \pm 3.22 b c \\
(71.43)\end{array}$ \\
\hline Petroleum ether & $\begin{array}{c}17.50 \pm 3.22 \mathrm{ab} \\
(14.29)\end{array}$ & $\begin{array}{c}23.75 \pm 4.26 b \\
(20.78) \\
\end{array}$ & $\begin{array}{c}43.75 \pm 2.39 \mathrm{c} \\
(41.56)\end{array}$ & $\begin{array}{c}62.50 \pm 5.20 \mathrm{c} \\
(61.04) \\
\end{array}$ \\
\hline Control & $3.75 \pm 2.39 b$ & $3.75 \pm 2.39 c$ & $3.75 \pm 2.39 d$ & $3.75 \pm 2.39 \mathrm{~d}$ \\
\hline
\end{tabular}

Values in the parenthesis are corrected mortality; values in the same column with a common letter are not significantly different at $P<0.05$ (Tukey's HSD test).

\section{Ovicidal activity of four different solvent extracts of $\boldsymbol{A}$. vera against $T$. urticae}

Ovicidal activities of four different solvent extracts were presented in Table 2 . At a concentration of $0.25 \%$, the highest mortality was observed in acetone extract, which is significantly different from control. All extracts showed significant egg mortality over control, with the exception of petroleum ether extract at the concentration of $0.50 \%$. Acetone extract showed higher mortality of eggs which is significantly different from other extracts at $1.0 \%$ concentration and control but no significant difference was observed between acetone and ethanol aloe extracts. At a concentration of $2 \%$, the acetone extract reached a mortality rate of $65.0 \%$ followed by ethanol (57.0\%), methanol (49.0\%) and the extract of petroleum ether $(40.0 \%)$. The ovicidal activities of acetone extract of the $A$. vera leaves have a good effect against $T$. urticae. Zhang et al. ${ }^{[23]}$ indicated that the acetone extracts of $A$. vera have higher oviposition activity against $T$. cinnabarinus. Kumral et al. ${ }^{[26]}$ also reported that ethanolic extracts from leaves and seeds of $D$. stramonium have acaricidal, oviposition deterrent activities against $T$. urticae. The egg mortality of $T$. urticae using methanol extract of river red gum Eucalyptus camaldulensis leaves was $63.26 \%{ }^{[27]}$. Hussen et al. ${ }^{[28]}$ reported that ethanol extract from the fruit of Capparis aegyptia was the least effective extract against $T$. urticae eggs. Derbalah et al. ${ }^{[29]}$ discovered that Nigella sativa Linn. (Ranunculaceae) (seeds) and Artemisia cina L. (leaf) (Asteraceae) extracts were toxic to eggs of T. urticae with $\mathrm{LC}_{50}$ values of 1850.92 and 2740.42 ppm. Ghaderi et al. ${ }^{[30]}$ observed that the ovicidal activity of methanolic extracts of $S$. meifolia, A. orientale, T. elliptica and $P$. viscosa against $T$. urticae eggs were 45.84, 41.40, 40.11 and $37.66 \%$ respectively. Auamcharoen et al. ${ }^{\text {[31] }}$ stated that crude methanol extracts of $D$. grandiflora extracts showed moderate repellency and also inhibited egg production in this mite species.

Table 2: Ovicidal activity of $A$. vera leaf extracts at different concentrations recorded 7 days after exposer (Mean \pm SE) (\%)

\begin{tabular}{|c|c|c|c|c|}
\hline \multirow{2}{*}{ Extracts } & \multicolumn{4}{|c|}{ \% Concentration } \\
\cline { 2 - 5 } & $\mathbf{0 . 2 5}$ & $\mathbf{0 . 5 0}$ & $\mathbf{1 . 0}$ & $\mathbf{2 . 0}$ \\
\hline Acetone & $18.00 \pm 4.16 \mathrm{a}$ & $32.00 \pm 1.63 \mathrm{a}$ & $58.00 \pm 5.29 \mathrm{a}$ & $65.00 \pm 4.12 \mathrm{a}$ \\
\hline Ethanol & $14.00 \pm 4.16 \mathrm{ab}$ & $22.00 \pm 5.29 \mathrm{a}$ & $46.00 \pm 3.46 \mathrm{ab}$ & $57.00 \pm 5.00 \mathrm{ab}$ \\
\hline Methanol & $11.00 \pm 4.43 \mathrm{ab}$ & $19.00 \pm 6.19 \mathrm{a}$ & $39.00 \pm 3.41 \mathrm{bc}$ & $49.00 \pm 2.51 \mathrm{bc}$ \\
\hline Petroleum ether & $11.00 \pm 3.41 \mathrm{ab}$ & $15.00 \pm 3.41 \mathrm{ab}$ & $29.00 \pm 3.41 \mathrm{c}$ & $40.00 \pm 3.65 \mathrm{c}$ \\
\hline Control & $0.00 \pm 0.00 \mathrm{~b}$ & $0.00 \pm 0.00 \mathrm{~b}$ & $0.00 \pm 0.00 \mathrm{~d}$ & $0.00 \pm 0.00 \mathrm{~d}$ \\
\hline
\end{tabular}

Values in the same column with a common letter are not significantly different at $P<0.05$ (Tukey’s HSD test)

Toxicity of four different solvent extracts of $A$. vera to $T$. urticae adults by topical spray

Acetone extracts of $A$. vera showed the highest acaricidal activities followed by ethanol, methanol and petroleum ether extracts (Table 3 ). The $\mathrm{LC}_{50}$ values after $24 \mathrm{~h}$ for adults were $0.45,0.67,0.95$ and 1.28 respectively, while for eggs 0.95 , $1.41,2.12$ and 3.31 were recorded after 7 days. The slope values of the regression line were 2.46, 1.97, 1.68 and 1.46 for adults and 1.51, 1.48, 1.35 and 1.14 for eggs respectively. LC $_{90}$ values were $1.48,3.00,5.51$ and 9.72 for adults and $6.68,10.32,18.75,43.67$ for eggs respectively (Table 3 ).

Zhang et al. ${ }^{[23]}$ found that the $\mathrm{LC}_{50}$ value of aloe acetone extract on $T$. cinnabarinus female were 0.836 and 0.167 $\mathrm{mg} / \mathrm{ml}$ for $42 \mathrm{~h}$ and $72 \mathrm{~h}$, respectively. Wei et al. ${ }^{[22]}$ also 
reported the $\mathrm{LC}_{50}$ values of aloe acetone extract against $T$. cinnabarinus were 0.614 and $0.099 \mathrm{mg} / \mathrm{ml}$ for $42 \mathrm{~h}$ and $72 \mathrm{~h}$, respectively. Wang et al. ${ }^{[32]}$, tested Juglans regia L. leaf extracts with different solvents and reported the $\mathrm{LC}_{50}$ values of 730, 1660, 4960, 7450 and 9910 ppm for the extract of petroleum ether, chloroform, ethyl acetate, methanol, and distilled water, respectively.

Table 3: Statistical comparison of $\mathrm{LC}_{50}$ values of four different $A$. vera extracts against $T$. urticae adults and eggs

\begin{tabular}{|c|c|c|c|c|c|c|c|c|}
\hline & \multicolumn{2}{|c|}{ Acetone } & \multicolumn{2}{c|}{ Ethanol } & \multicolumn{2}{c|}{ Methanol } & \multicolumn{2}{c|}{ Petroleum Ether } \\
\cline { 2 - 9 } & Adult & Egg & Adult & Egg & Adult & Egg & Adult & Egg \\
\hline LC50 (\%) & 0.446 & 0.950 & 0.667 & 1.406 & 0.953 & 2.115 & 1.279 & 3.312 \\
\hline Lower limit & 0.375 & 0.558 & 0.556 & 1.122 & 0.780 & 1.560 & 1.002 & 2.118 \\
\hline Upper limit & 0.518 & 2.328 & 0.796 & 1.936 & 1.209 & 3.505 & 1.815 & 8.100 \\
\hline Slope \pm SE & $2.459 \pm 0.27$ & $1.514 \pm 0.20$ & $1.966 \pm 0.24$ & $1.480 \pm 0.21$ & $1.681 \pm 0.23$ & $1.352 \pm 0.22$ & $1.455 \pm 0.23$ & $1.144 \pm 0.22$ \\
\hline$\chi^{2}$ (df) & $1.838(2)$ & $2.623(2)$ & $1.470(2)$ & $1.676(2)$ & $0.881(2)$ & $0.077(2)$ & $1.025(2)$ & $0.614(2)$ \\
\hline LC90 (\%) & 1.481 & 6.676 & 2.994 & 10.324 & 5.518 & 18.746 & 9.722 & 43.667 \\
\hline
\end{tabular}

The original insect mortality data were corrected by Abbott's (1925) formula before analysis, $\chi^{2}=$ Goodness of fit, $\mathrm{df}=$ Degrees of freedom, The tabulated value of $\chi^{2}$ is $5.99(\mathrm{df}=2)$

\section{Repellent effect of four different solvent extracts of $A$. vera against $T$. urticae}

The effects of the four different extracts of $A$. vera leaves and doses are presented in Table 4. Of the extracts, ethanol showed the highest repellency effect $(95.00 \%)$ followed by acetone (87.50\%), methanol (77.50\%), petroleum ether (70.00\%) at a $2 \%$ concentration. The number of eggs laid by females significantly decrease compared to the control. For egg laying the repellency effects of acetone, methanol and petroleum ether extracts were statistically at par compared to the ethanol. Kumral et al. ${ }^{[26]}$ reported that ethanol extracts from $D$. stramonium leaf and seed have repellent and reproduction inhibition activities against $T$. urticae. Kundu et al. [33] investigated the repellent effect of biskatali plant extract in two solvents namely ethyl alcohol and chloroform against red flour beetle. They found that ethyl alcohol and chloroform have a repellent effect on Tribolium castaneum. Antonious et al. ${ }^{[34]}$ found that ethanol extracts of wild tomato leaves have been found to have a strong repellency effect on T. urticae. Hussein et al. ${ }^{[28]}$ observed that a higher percentage of repellency was recorded in the ethanol extract of fruits and leaves (96.42 and $86.67 \%$ ) of Capparis aegyptia. ElSharabasy ${ }^{[35]}$ evaluated the repellent effect of crude extracts of $A$. judaica L. against adult females and immature stage of T. urticae. They found that leaf extraction with ethanol was most effective as a repellent effect against adult females and immature stage of $T$. urticae followed by acetone, petroleum ether and aqueous extraction. Teklay et al. ${ }^{[36]}$ studied the insecticidal and repellent properties of garlic, tobacco, neem and Aloe vera extracts. All the plant extracts repelled the insects completely. Mostafa et al. ${ }^{[37]}$ reported that the acetone, methanol and water extracts from mahagoni (Swietenia mahagoni) leaf showed larvicidal, antifeedant and insect repellent activity against the red flour beetle, $T$. castaneum.

Table 4: Repellent effect of four different $A$. vera leaf extracts against of $T$. urticae after $24 \mathrm{~h}$ of exposure

\begin{tabular}{|c|c|c|c|c|c|}
\hline \multirow{2}{*}{ Solvent } & \multirow{2}{*}{$\%$ Concentrations } & \multirow{2}{*}{ \% Repellency } & \multirow{2}{*}{ Repellency Class } & \multicolumn{2}{|c|}{ Average no. of eggs/ female after $24 \mathrm{~h}$} \\
\hline & & & & Treated & Control \\
\hline \multirow{4}{*}{ Acetone } & 0.25 & 65 & IV & \multirow{4}{*}{$2.75 b c$} & \multirow{4}{*}{43.13} \\
\hline & 0.50 & 75 & IV & & \\
\hline & 1.0 & 85 & $\mathrm{~V}$ & & \\
\hline & 2.0 & 87.5 & $\mathrm{~V}$ & & \\
\hline \multirow{4}{*}{ Ethanol } & 0.25 & 77.5 & IV & \multirow{4}{*}{$1.87 \mathrm{c}$} & \multirow{4}{*}{45.12} \\
\hline & 0.50 & 80 & IV & & \\
\hline & 1.0 & 82.5 & $\mathrm{~V}$ & & \\
\hline & 2.0 & 95 & $\mathrm{~V}$ & & \\
\hline \multirow{4}{*}{ Methanol } & 0.25 & 45 & III & \multirow{4}{*}{$5.18 \mathrm{bc}$} & \multirow{4}{*}{34.43} \\
\hline & 0.50 & 55 & III & & \\
\hline & 1.0 & 70 & IV & & \\
\hline & 2.0 & 77.5 & IV & & \\
\hline \multirow{4}{*}{ Petroleum ether } & 0.25 & 45 & III & \multirow{4}{*}{$7.06 \mathrm{~b}$} & \multirow{4}{*}{41.18} \\
\hline & 0.50 & 52.5 & III & & \\
\hline & 1.0 & 62.5 & IV & & \\
\hline & 2.0 & 70 & IV & & \\
\hline Water & & 35 & II & $36.25 a$ & 51.00 \\
\hline
\end{tabular}

Means in the same column followed by the different letters are significantly different at $P<0.05$ (Tukey’s test)

\section{Residual effects of four different solvent extracts of $A$. vera} against $T$. urticae

The residual effects of the acetone, ethanol, methanol and petroleum ether extracts were presented in Figure 1. In the residual test, the mortality of $T$. urticae varied appreciably. One hour after treatment, acetone extracts show higher mortality (48.75\%) followed by ethanol (42.50\%), methanol (28.75\%) and petroleum ether extract (25.00\%). Twenty four hours after treatment, all extracts showed significantly different mortality rates than the untreated control. Acetone has a higher mortality rate than all other treatments. However, there was no significant difference was observed among acetone and ethanol, methanol and petroleum ether extract, respectively. The mortality percentage decreased after 48 and 72 hours of treatments. 


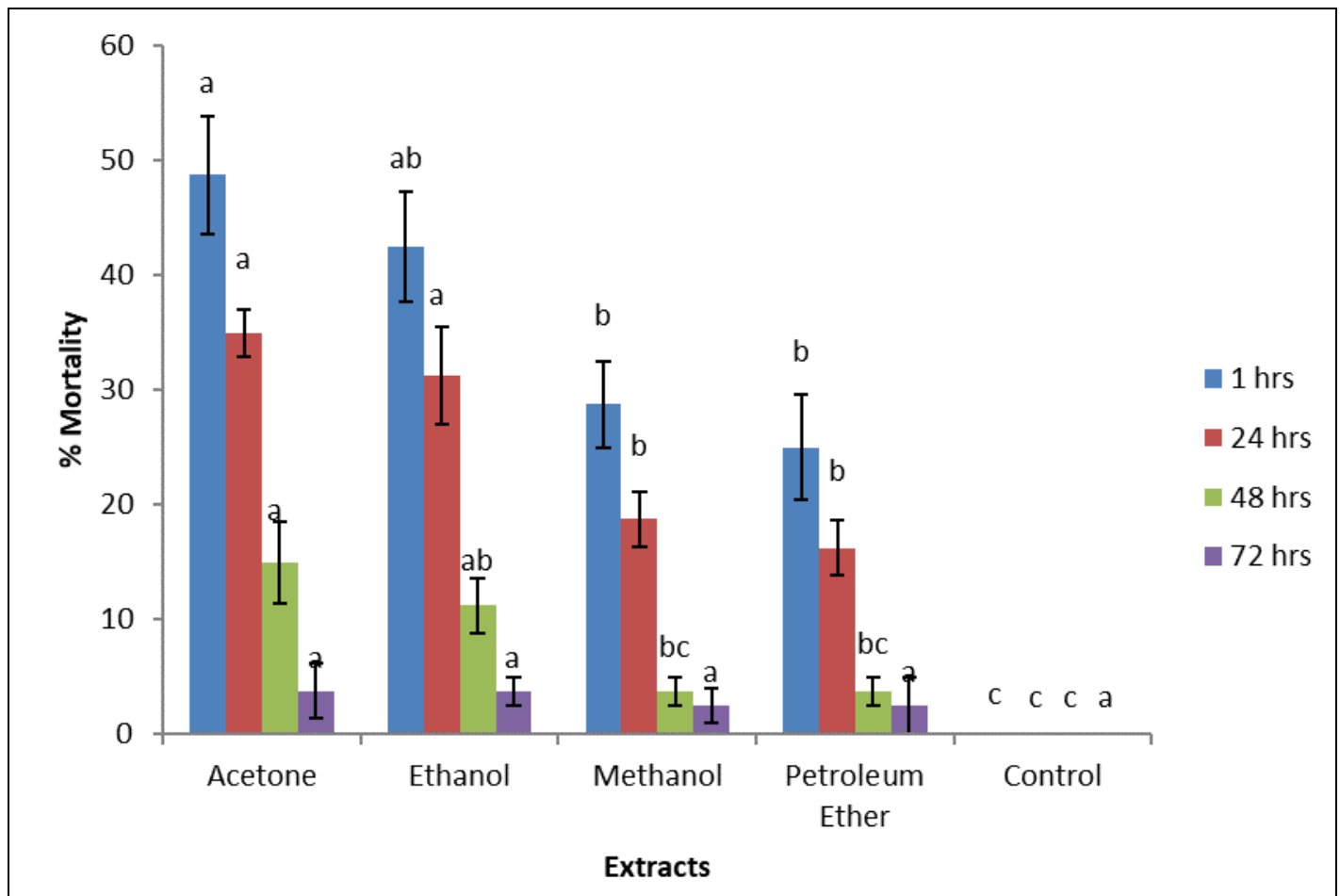

Fig 1: Persistence of A. vera leaf extracts against $T$. urticae at 1,24,48 and 72 hours old residue of LC 50 values. [Bars marked with same letter do not differ significantly $(P<0.05)]$

\section{Acknowledgement}

Authors are gratefully acknowledged to the University Grants Commission (UGC), Bangladesh with the coordination of Institute of Research and Training (IRT), HSTU for providing financial support to undertake the present studies.

\section{References}

1. Vassiliou VA. Kitsis P. Acaricide resistance in Tetranychus urticae (Acari: Tetranychidae) populations from Cyprus. Journal of Economic Entomology 2013;106:1848-1854.

2. Park YL. Lee JH. Leaf cell and tissue damage of cucumber caused by two-spotted spider mite (Acari: Tetranychidae). Journal of Economic Entomology 2002;95:952-957.

3. Zhang ZQ. Mites of greenhouses: identification, biology and control. London, UK: CABI 2003.

4. Riahi E, Nemati A, Shishehbor P, Saeidi Z. Population growth parameters of the two-spotted spider mite, Tetranychus urticae, on three peach varieties, in Iran. Acarologia 2011;51(4):473-480.

5. Kim YK, Lee MH, Jee YK, Hong SC, Bae JM, Chang YS et al. Spider mite allergy in apple-cultivating farmers: European red mite (Panonychus ulmi) and two-spotted spider mite (Tetranchus urticae) may be important allergens in the development of work-related asthma and rhinitis symptoms. J Allergy Clin. Immunol 1999;104:1285-1292.

6. Kumral NA, Cobanoglu S, Yalcin C, Acaricidal, repellent and oviposition deterrent activities of Datura stramonium L. against adult Tetranychus urticae (Koch). Journal of Pest Science 2010;83:173-180.

7. Choi WI, Lee EH, Choi BR, Park HM, Ahn YJ. Toxicity of plant essential oils to Trialeurodes vaporariorum (Homoptera: Aleyrodidiae). Journal of Economic Entomology 2003;96:1479-1484.

8. Lee YS, Song MH, Ahn KS, Lee KY, Kim JW Shin SC, Kim GH. Monitoring of acaricide resistance in two- spotted spider mite (Tetranychus urticae) populations from rose green houses in Korea. Journal of Asia Pasific Entomology 2003;5:237-240.

9. Sing RN. Saratchandra B. The development of botanical products with special reference to Seri-ecosystem. Caspian Journal Environmental Science 2005;3:1-8.

10. Keitaa SM, Vincent C, Schmita JP, Arnasonc JT, Be'langer A. Efficacy of essential oil of Ocimum basilicum L. and O. gratissimum L. applied as an insecticidal fumigant and powder to control Callosobruchus maculatus (Fab.) [Coleoptera: Bruchidae]. Journal of Stored Products Research 2001;37: 339-349.

11. Rahman MF. Siddiqui M. Biochemical effects of vepacide (from Azadirachta indica) on Wistar rats during subchronic exposure. Ecotoxicology and Environmental Safety 2004;59(3):332-339.

12. Correia AA, Wanderley-Teixeira V, Teixeira AA, Oliveira JVD, Torres JB. Morfologia do canal alimentar de lagartas de Spodoptera frugiperda (JE Smith) (Lepidoptera: Noctuidae) alimentadas com folhas tratadas com nim. Neotropical Entomology. 2009;38(1):83-91.

13. Ghazawy NA, Awad HH, Abdel Rahman KM. Effects of azadirachtin on embryological development of the desert locust Schistocerca gregaria Forskål (Orthoptera: Acrididae). Journal Orthopaedic Research 2010;19(2):327-332.

14. Fu XL, Gao WQ, Wang NL, Wang HJ. The study situation on chemical composition of Aloe. Guang Dong Chemical 2008;10:99-102.

15. Yao LH, He GQ, Chen QH. Research progress on biologically active component of aloe and their functional mechanism. Bulletin of Science, Technology and Society. 2007;6:812-815.

16. Morsy TA, El-Ela RGA, Nasser MMI, Khalaf SAA, Mazyad SAM. Evaluation of the in-vitro pediculicidal action of four known insecticides and three medicinal plant extracts. Journal of the Egyptian Society of 
Parasitology 2000;30:699-708.

17. Wei J, Ding W, Zhao YG, Patcharaporn V. Acaricidal activity of Aloe vera L. leaf extracts against Tetranychus cinnabarinus (Boisduval) (Acarina: Tetranychidae). Journal of Asia-Pacific Entomology 2011;14:353-356.

18. Abbott WS. A method of computing the effectiveness of an insecticide. Journal of Economic Entomology 1925;18:265-267.

19. McDonald LL, Guy RH, Speirs RD. Preliminary evaluation of new candidate minerals as toxicants, repellents and attractants against stored product insects-I. Marketing Research Report No. 882. Agricultural Research Service, U. S. A. Department of Agriculture. Washington D. C 1970, 8.

20. McGovern TP, Gillenwater HB, McDonald LL. Repellents for adults Tribolium confusum: mandelates. Journal of Georgia Entomological Society 1977;12:7989.

21. Robertson JL, Russel RM, Preisler HK, Saven ME. Bioassay with Arthopods: Polo: A new computer programme. C. R. C. Fransis and Taylor 2007, 1-24.

22. Wei J, Ding W, Zhao YG, Patcharaporn V. Acaricidal activity of Aloe vera L. leaf extracts against Tetranychus cinnabarinus (Boisduval) (Acarina: Tetranychidae). Journal of Asia-Pacific Entomology 2011;14:353-356.

23. Zhang Q, Ding LJ, Li M, Cui WW, Wei D, Luo JX et al. Action modes of Aloe vera L. extracts against Tetranychus cinnabarinus Boisduval (Acarina: Tetranychidae). Journal of Agricultural Science. 2013;4:117-122.

24. Zang Y, Zhang Q, Luo J, Ding W. Acaricidal active fractions from acetone extract of Aloe vera L. against Tetranychus cinnabarinus and Panonychus citri. Acta Physiologiae Plantarum. 2017;39:195.

25. Amer SAA, Reda AS, Dimetry NZ. Activity of Abrus precatorius L. extracts against the two-spotted spider mite Tetranychus urticae Koch. (Acari: Tetranychidae) Acarologia 1989;30:209-219.

26. Kumral NA. Cobanoğlu S. Yalcin C. Acaricidal, repellent and oviposition deterrent activities of Datura stramonium $\mathrm{L}$ against adult Tetranychus urticae Koch. Journal of pesticide Science 2009;83:173-180.

27. Yanar Y, Kadiolu I, Gökçe A, Demirta I, Gören N, Çam $\mathrm{H}$, Whalon $\mathrm{M}$. In vitro antifungal activities of 26 plant extracts on mycelial growth of Phytophthora infestans (Mont.) de Bary. African Journal of Biotechnology 2011;10(14):2625-2629.

28. Hussein H, Abou-elela M, Amer SAA, Momen FM. Repellency and toxicity of extracts from Capparis Aegyptia to Tetranychus urticae Koch (Acari: tetranychidae). Acarologia, 2005, 2006;XLVI(3, 4):221226.

29. Derbalah AS, Keratum YA. El-dewy ME. El-Shamy EH. Efficacy of some insecticides and plant extracts against Tetranychus urticae under laboratory conditions, Egypt. Journal of plant protection Research 2013;1(3):46-68.

30. Ghaderi S, Kambiz M, Rowshan V, Ghamadyari M. Toxicity and ovicidal activity of different plant extracts on two-spotted spider mite, Tetranychus urticae Koch (Acari: Tetranychidae). Archives of Phytopathology and Plant Protection 2013;46(1):120-126.

31. Auamcharoen W, Chandrapatya A. Potential Control of Two-Spotted Spider Mite, Tetranychus urticae Koch (Acari: Tetranychidae) by Crude Extracts of Duabanga grandiflora (Lythraceae) and Diospyros cauliflora
(Ebenaceae). Pakistan Journal of Zoology 2015;47(4):953-964.

32. Wang YN, Shi GL, Zhao LL, Liu SQ. Clarke SR. Sun $\mathrm{JH}$. Acaricidal activity of Juglans regia leaf extracts on a Tetranychus viennensis and Tetranychus viennensis and Tetranychus cinnabarinus (Acari: Tetranychidae). Journal of Economic Entomology. 2007;100:1298-1303.

33. Kundu BR, Ara R, Begum M, Sarker ZI. Effect of biskatali Polygonum hydropiper L. plant extracts against red flour bettle, Tribolium castaneum Herbst. University. Journal of Zoology, Rajshahi University 2007;26:3-87.

34. Antonious GF, Snyder JC. Natural products: repellency and toxicity of wild tomato leaf extracts to the twospotted spider Mite, Tetranychus urticae Koch. Journal of Environmental Science and Health, Part B 2006;41(1):43-55.

35. El-Sharabasy HM. Acaricidal activities of Artemisia judaica L. extracts against Tetranychus urticae Koch and its predator Phytoseiulus persimilis Athias-Henriot (Tetranychidae: Phytoseiidae). Journal of Biopesticides. 2010;3(2):514-519.

36. Teklay M, Prasad SH, Behailu KR, Kinetibeb B, Tewodros A. Insecticidal and repellent properties of selected medicinal plants collected from Sofoho, Axum and North-East Africa. International Journal of Integrative Sciences, Innovation and Technolohy 2012;1(3):1-8.

37. Mostafa M, Hemayet H, Hossain MA, Biswas PK, Haque MZ. Insecticidal activity of plant extracts against Tribolium castaneum Herbst. Journal of Advance Science Research 2012;3(3):80-84. 